\title{
ANALYSIS OF MASPIN EXPRESSION IN INVASIVE DUCTAL CARCINOMA OF THE BREAST ON STAGES IIA AND IIIB
}

\author{
Arif Satria Hardika, Dyah Fauziah \\ Department of Anatomic Pathology, Faculty of Medicine, Universitas Airlangga, Dr. Soetomo Hospital, Surabaya
}

\begin{abstract}
ABSTRAK
Mammary Serine Protease Inhibitor (maspin) merupakan gen penekan tumor, merupakan anggota dari keluarga serin protease inhibitor (serpin) yang bekerja dengan menghambat motilitas pergerakan sel, invasi dan metastase. Ekspresi Maspin diharapkan dapat menjadi suatu faktor prognostik serta faktor prediktif pada tumor mamma. Akan tetapi, pada beberapa penelitian terbaru, maspin memiliki ekspresi yang beragam. Meskipun diketahui tidak adanya maspin yang muncul sebagai indikator progresifitas tumor dan metastasis, penelitian terbaru justru menunjukkan bahwa ekspresi maspin berkaitan dengan fenotipe agresif pada kanker payudara serta dengan prognosis yang buruk. Korelasi antara ekspresi maspin dan prognosis yang buruk juga pernah dilaporkan pada kanker pankreas, ovarium, thyroid, kandung kemih dan paru. Pengetahuan tentang ekspresi dan peran maspin ini serta hubungannya dengan patogenesa karsinoma duktal invasif payudara masih sedikit. Tujuan penelitian ini adalah untuk melihat perbedaan ekspresi maspin pada karsinoma duktal invasif payudara kelompok stadium IIA dan stadium IIIB. Metode penelitian ini menggunakan penelitian observasional analitik dengan pendekatan crosssectional. Sampel penelitian adalah blok parafin Invasive carcinoma of NST di Departemen Patologi anatomi RSUD Dr Soetomo Surabaya selama Januari - Desember 2015. Tiga puluh sampel dibagi dalam dua kelompok, yaitu kelompok stadium IIA dan Stadium IIIB dan dilakukan pemeriksaan imunohistokimia dengan antibodi maspin. Perbedaan ekspresi maspin pada stadium IIA dan stadium IIIB dianalisis dengan uji statistic MannWhitney test. Terdapat perbedaan ekspresi maspin yang signifikan antara kelompok stadium IIA dan stadium IIIB, dimana stadium IIA memiliki ekspresi maspin yang tinggi daripada stadium IIIB. (FMI 2018;54:6-9)
\end{abstract}

Kata kunci: Karsinoma duktal invasif payudara stadium IIA dan IIIB; maspin

\begin{abstract}
Mammary Serine Protease Inhibitor (maspin) is a tumor suppressor gene, a member of the serine protease inhibitor (serpin) family that works by inhibiting motility of cell movement, invasion and metastasis. Maspin expression is expected to be a prognostic factor as well as a predictive factor in mammary tumors. However, in some recent studies, maspin has a variety of expressions. Although it is known that no maspine appears as an indicator of tumor progression and metastasis, recent study has shown that maspine expression is associated with an aggressive phenotype of breast cancer and with a poor prognosis. Correlations between maspine expression and poor prognosis have also been reported in pancreatic, ovarian, thyroid, bladder and lung cancers. Knowledge of the expression and role of this maspin as well as its relationship with the pathogenesis of breast invasive ductal carcinoma is still small. The aim of this study was to look at differences in maspin expression in breast-invasive ductal carcinoma of stage IIA and stage IIIB groups. This research method used analytic observational research with cross sectional approach. The samples were invasive carcinoma of NST paraffin at the Department of Anatomic Pathology of Dr Soetomo Hospital, Surabaya, from January to December 2015. Thirty samples were divided into two groups, namely stage IIA and stage IIIB groups and immunohistochemical examination with maspin antibody was carried out. The difference of maspin expression in stage IIA and stage IIIB was analyzed using MannWhitney statistic test. There were significant differences in maspin expression between stage IIA and stage IIIB groups, where stage IIA has a high maspin expression rather than stage IIIB. (FMI 2018;54:6-9)
\end{abstract}

Keywords: Invasive breast cancer stages IIA and IIIB; maspin

Correspondence: Arif Satria Hardika, Jalan Jambangan Kebon Agung II/35 Surabaya, Indonesia. Email: arsat03@yahoo.com

\section{INTRODUCTION}

Mammary Serine Protease Inhibitor (Maspin) is a tumor suppressor gene, a member of the serine protease inhibitor family (serpin) and located on chromosome 18q21.3-q23, a place that often suffers from heterozygous loss (Bodenstine et al., 2012). Maspin has been known as tumor suppressor gene, inhibits motility of cell movement, invasion and metastasis. Maspin can also increase cell sensitivity in apoptotic processes and inhibit angiogenesis processes. (Bodenstine et al 2012, Berrardi et al 2013). Maspin expression is expected to be a prognostic factor as well as a predictive factor in mammary tumors so that it can be used in therapy (Berardi et al 2013). 
However, in some recent studies, maspin has diverse expression (Berardi et al 2013). Although it is known that no maspine appears as an indicator of tumor progression and metastasis, recent research has shown that maspine expression is associated with an aggressive phenotype of breast cancer and with a poor prognosis. Correlations between maspine expression and poor prognosis have also been reported in other organs in pancreatic, ovarian, thyroid, bladder and lung cancers (Berardi et al 2013, Bodenstine et al 2012). There is little knowledge of maspin's expression and role and association with the pathogenesis of breast cancer (Berardi et al 2013). Stark et al (2010) and Mass et al ave examined the potential relationship between maspine expression in primary tumors and metastases. They showed that maspin expression decreased in primary tumors and decreased in metastasis (Maass et al 2001, Berardi et al 2013).

The opposite study was reported by Umekita et al (2011) who trace 92 and 192 patients of breast invasive ductal carcinoma. They reported that maspin expression was commonly found in breast invasive ductal carcinoma with aggressive phenotype (high histological grade) and was a poorly prognostic indicator (Berardi et al. 2013, Umekita et al 2002). In addition Umekita and Yoshida (2003) and Lee et al (2006) also reported large tumor size, high histologic grade, positive P53 status as well as negative estrogen and progesterone receptor status and poor prognosis associated with maspine expression (Umekita et al 2011, Berardi et al 2013).

Further research is needed to clarify the true mechanism of excess maspine expression in breast cancer, as well as to use it as a prognostic marker in clinical practice (Berrardi et al. 2013). This study was aimed to determine the potential role of maspin based on tumor stage in breast invasive ductal carcinoma of stage IIA group and stage IIIB. In this study will assess maspin expression and its correlation as well as its role as a prognostic factor in breast invasive ductal carcinoma using immunohistochemical methods.

\section{MATERIALS AND METHODS}

The study design used was analytic observational with cross sectional approach. The study population was 30 paraffin blocks of patients with invasive breast cancer in the Anatomic Pathology Laboratory of Dr. Soetomo Hospital, Surabaya, from January to December 2015. We obtained the data randomly and divided the samples into two, which were stage IIA and stage IIIB groups.

Maspin expression was examined immunohistochemically using the monoclonal mouse anti-human antibody from Santa Cruz Biotechnology using 1:125 dilution. Positively stained tumor cells were counted visually using binocular photon micro-scope at 400x magnification, and grading was made according to percentage and intensity of positively stained cells.

Maspin expressions were considered positive if the cytoplasm was stained. The maspin marking was expressed as a percentage of cells that were positively stained and the intensity of stained cells, then categorized in the following scores: Cell percentage, it had negative value if cell was not stained, one value if positive cells were $1-5 \%$, two if positive cells were 1$5 \%$, three if the positive cells were $6-50 \%$ and three if the cells are positive $>50 \%$. Cell Intensity, negative if cell is unbound, value one if intensity is weak, two if medium intensity, three if intensity is strong. The final score is the total percentage score and the cell intensity, having a total weak score if the total score is $1-2$, while the total score is 3-4 and strong if the total score is 5-6 (Sopel et al 2005).

Data obtained were statistically analyzed. The difference of maspin and VEGF expressions were analysed using the Mann-Whitney and Spearman test $(\mathrm{p}<0.05)$.

\section{RESULTS}

Thirty subjects in this study had the mean age of 54.70 \pm 10.31 years old. The youngest subject was 40 years old and the oldest was 82 years old. In the stage IIA group (15 subjects), the mean age was $56.07 \pm 11.25$ years old, 41 years old as the youngest subject age and 82 years as the oldest; the stage IIIB group (15 subjects) had the mean age of $53.33 \pm 9.47$ years old, 40 years old as the youngest subject and 71 years as the oldest. In the chi-square test, there was no significant difference on the age distribution between stage IIA and stage IIIB groups.

In this study, maspin expression was graded in each sample group based on the cell percentage with score of 0-3 and the cell intensity with score of $0-3$ as well as the total score of weak 1-2, moderate 3-4, and strong 5-6. These results were obtained: weak maspin expression in stage IIA group of 7 subjects $(43.8 \%)$ and stage IIB group of 9 subjects $(56.3 \%)$; moderate maspin expression in stage IIA group of 7 subjects $(43.8 \%)$ and stage IIIB group of 9 subjects $(56.3 \%)$; and strong maspin expression in stage IIA group of 0 subject $(0 \%)$ and stage IIIB group of 2 subjects (13.3\%). Using Mann-Whitney test, there was significant differences in maspin expressions between stage IIIB group compared to stage IIA group $(\mathrm{p}<0.05)$. 
Table 1. Maspin expression using Mann-Whitney test

\begin{tabular}{ccccccc}
\hline $\begin{array}{c}\text { Maspin } \\
\text { expression }\end{array}$ & Stages & Median & $\begin{array}{c}\text { Interquartile } \\
\text { deviation }\end{array}$ & Min & Max & $\mathrm{p}$ \\
\hline Presentation & IIA & 3 & 0.0 & 2 & 3 & $0.008^{*}$ \\
& IIIB & 2 & 0.5 & 1 & 3 & \\
Intensity & IIA & 2 & 0.5 & 1 & 3 & 0.306 \\
& IIIB & 1 & 0.5 & 1 & 3 & \\
Intensity \& & IIA & 5 & 0.5 & 3 & 6 & $0.034^{*}$ \\
Presentation & IIIB & 3 & 1.0 & 2 & 6 & \\
\hline
\end{tabular}

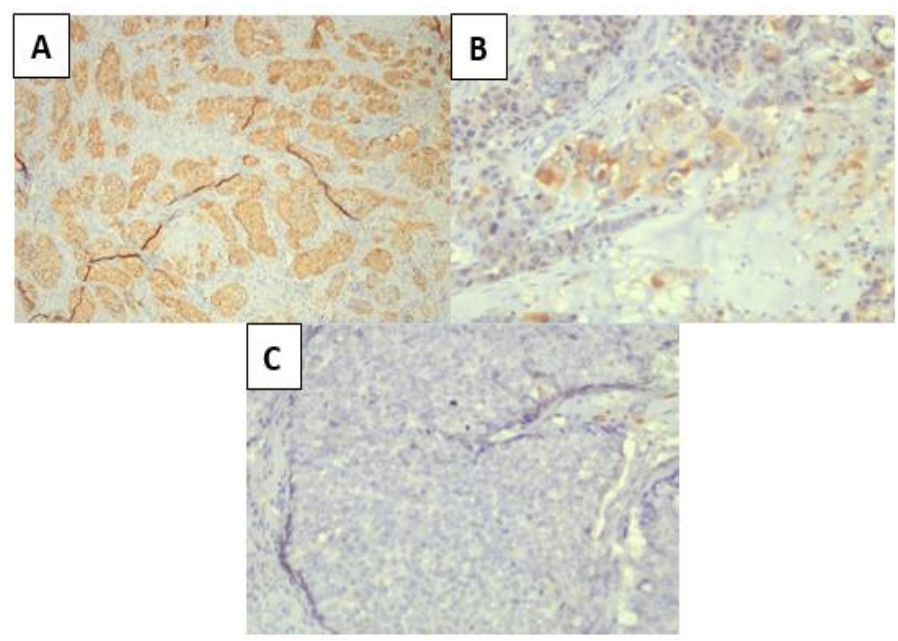

Fig. 1. Maspin expression using high-intensity microscope in figure A (HE, 40x), medium-intensity in figure B (HE, 100x) and low-intensity in figure C (HE, 100x).

\section{DISCUSSION}

Maspin is detected in normal breast and epithelial cells of the prostate, but in tumor cells its expression is lower (Berardi et al 2013). Maspin expression in breast cancer prevents invasion in vitro and metastasis in vivo. Loss of gene expression induces raise of invasion and spread of breast cancer (Bodenstine et al 2012).

There are varied results regarding maspin activity; in some cases it is known to correlate with better prognosis in mammary and prostate tumors. This is shown with the loss of maspin expression in invasive and aggressive mammary tumors. This places maspin in the list of metastasis suppressor genes potentially involved in metastasis (Berardi et al 2013).

According to the spread pattern of maspin expression, in stage IIA group, most of the maspin expression shown were moderate expression, in 8 cases $(66.7 \%)$, followed by 7 weak expressions (43.8\%) and no strong expression. In stage IIIB group, most of the maspin expression shown were weak expression, in 9 cases $(56.3 \%)$, followed by 4 moderate expressions $(33.3 \%)$ and 2 strong expressions (11.3\%). Statistical analysis between maspin and staging status in this study showed that there was significant difference $(\mathrm{p}=0.034)$. Stage IIA group had tendency to show stronger maspin expression compared to the stage IIIB group. This result is consistent with previous studies (Berardi et al 2013). The difference of maspin expression between low- and highexpression groups are consistent with role of maspin as the tumor suppressor gene by inhibiting motiliy, invasion and metastasis of cells, also elevates cell sensitivity against apoptosis process and inhibiting angiogenesis process (Jiang et al 2002, Maass et al 2000, Streuli 2002).

\section{CONCLUSION}

There was a difference in maspin expression in breast invasive ductal carcinoma of stage IIA and IIIB groups. Maspin expression was higher in the IIA stage group than that in IIIB stage group. This is in accordance with maspin function as tumor suppressor gene by inhibiting 
motility of cell movement, invasion, angiogenesis and metastasis.

\section{REFERENCES}

Berardi R, Morgese F, Onofri A, Mazzanti P, Pistelly $\mathrm{M}$, et al (2013). Role of maspin in cancer. Clinical and Translational Medicine 2, 8

Bodenstine TM, Seftore RE, Khalkhali-Ellis Z, Seftor EA, Pemberton PA, Hendrix MJ (2012). Maspin: molecular mechanisms and therapeutic implications. Cancer Metastasis Rev 31, 529-51

Jiang N, Meng Y, Zhang S, Osman E, Sheng S (2002). Maspin Sensitizes Breast Carcinoma Cells to Induced Apoptosis. Oncogene 21, 4089-4098

Lee MJ, Suh CH, Li Zh (2006). Clinicopathological significance of maspin in breast cancer. J Korean Med Sci 21, 309-14

Maass N, Hojo T, Zhang M, Sager M, Jonat R, Nagasaki K (2000). Maspin-A novel protease inhibitor with tumor-suppressing activity in breast cancer. Review Article, Octa Oncologica, 186

Maass N, Teffner M, Rosel F, Pawaresch R, Jonat W, Nagasaki K (2001). Decline in the expression of the serine proteinase inhibitor maspin is associated with tumour progression in ductal carcinomas of the breast. Journal of pathology 195, 321-326

Stark AM, Christian S, Maass N, Hugo HH, Jonat W, Mehdorn M, Held Feindt (2010). Expression of metastasis suppressor gene maspin is reduced in breast cancer brain metastasis and correlates with the estrogen receptor status. Neurological research 32

Streuli CH (2002). Commentary: maspin is a tumor suppressor that inhibits breast cancer tumours metastasis in vivo. Breast Cancer Research 4, 137-140

Umekita Y, Ohi Y, Sagara Y, Yoshida H (2002). Expression of maspin predicts poor prognosis in breast cancer patients. Int. J. Cancer 100, 452-455

Umekita Y, Ohi Y, Souda M, Rai Y, SagaraY, Sagara Y, Tamada S, Tanimoto A (2011). Maspin expression is frequent and correlates with basal markers in triple negative breast cancer. Diagnostic Pathology 6, 36

Umekita Y, Yoshida H (2003). Expression of maspin is up regulated during the progression of mammary ductal carcinoma. Department of Pathology, faculty of medicine, Kagoshima University, Histopatology 42, 541-545 